\title{
A Response to “Listening with Displacement”
}

\author{
Rihab Azar
}

ABSTRACT: Can collaborative, transparent, and open-ended inquiries empower social activism and grassroot change? In my response to "Listening with Displacement," I argue that it can and that it should. In an age full of unhelpful and dangerous narratives of displacement, I suggest that anthropologists are very well-positioned to take their role a step further to facilitate social understanding and cohesion as they collaboratively explore and create points of contact with and for their subjects.

KEYWORDS: compassion, decolonisation, empathy, migration, mindfulness, music

A few days after participating in the Beyond Borders Scotland festival, I finally started writing this response to Tom Western's article, "Listening with Displacement," with (personally) much-needed conviction. Having been in the inspiring company of world-renowned composer Nigel Osborne and three wonderful women musicians in Scotland, I returned to London full of a sense of hope and companionship. "Music and Migration" was the title of our two performances: a presentation and a promenade in the woods. Osborne talked about the origins of the instruments - barbat, rababa, and rock gongs - and how they were shared and transformed into other versions such as lute, violin, cello, and metal gongs as "they" migrated. Through our instruments and with a suitable repertoire, we were able to communicate the sounds of different instruments and types of music. This sharing of historical knowledge supported by sound allowed the audience to reflect on how instruments that are familiar to them came about thanks to the knowledge shared through migration.

Osborne encouraged the audience to reflect on how migration, which is a rich source of knowledge sharing, has been increasingly perceived as something bad in many people's minds. Indeed, what inspires me most about Nigel Osborne is his intellectual activism through his aid work and relational approach to global issues, working restlessly in Lebanon with the civil society organization Sawa, ${ }^{1}$ as well as in Bosnia-Herzegovina, Georgia, and many other countries (Morris 2018). It is this relationality, and the combination of critical reflection and activism, that I focus on in the remainder of this short response to Tom Western's piece.

\section{Beyond "Representations" and Narratives of Migration}

In his thought-provoking article, which starts by stressing the importance of disrupting mainstream modes of representing displaced people, Western sets out his "work with methods that combine ethnography with historical investigation and experiments in documentation, centering on collaborative practices of soundwalks and location recording ... [to explore] the 
sonic politics of everyday life for those who have crossed borders, how migrant activisms fit into broader urban struggles, and how these experiences map onto histories of movement and migration in the city." As I was reading the article, I found myself moving away from discussing the method itself toward building on some of his arguments and voicing my perspectives on the potential of the direction of thought presented by Western.

I come from Syria, from a region that has long been suffering unrest, and I speak for many people when I say we are tired of being questioned and tired of sharing aspects of our very personal lives with academia (and the media) while all we get "in return" is "being represented." I, and people in a similar situation to me, carry much historical frustration and a deep sensitivity to questions like "Do you like it here?" "Would you go back home?" and "How did you come here?" My personal experience with the media since I arrived in the UK has taught me not to give anybody the permission to represent me. In the words of Boaventura de Sousa Santos, "We do not want to be spoken about. We want to speak for ourselves. We do not want to be seen on the other side of the line. We want to eliminate the line" (Santos 2015: 307). Over time, I developed the confidence to correct others when they assign to me adjectives that do not communicate who I truly am. In turn, I do not claim to represent anybody.

At the same time, Santos (ibid.: 275) speaks of the "impossibility of collective authorship." He views his awareness of how he separates himself from a collective (in order to write) as a practice and manifestation of his belonging to that collective. He describes a "double absence" of "that which could be formulated only collectively, were it susceptible to rational formulation, and the absence of that which cannot be formulated, either individually or collectively" (ibid.: 323).

Following this, it is essential to note that disrupting unhelpful, and often dangerous, narratives of displacement is not and should not be the job of the displaced. In the end, if knowing neither of the continuous suffering and tragic death of others, nor of the remarkable resilience of survivors is able to engage people, how could any representational method work? It is for this reason that "Listening with Displacement" is important, in my view, mostly as a social practice, rather than as an ethnographic method per se.

Before turning to the importance of such forms of social practice, a few words on the limits of anthropology, and social science research more generally, are warranted at this stage. First, as is by now widely acknowledged, and as I know from firsthand experience, anthropologists do not always fully inform their subjects about aspects such as funding sources, the potential of the research, the bigger picture, or the outcomes (or lack thereof) that might (or might not) affect them (and others). Equally, the knowledge gathered through ethnography is rarely made available in their language simultaneously with the very first publication, with the insights learned (or interpreted) in the process of an anthropological case remaining something that the "subjects" themselves are not aware of (Carrier 2012). While data itself can of course reveal a great deal about "the science" itself (Gardner and Lewis 2015), making the analysis accessible to the subjects of the research is crucial, ethically and politically speaking.

If we take as a starting point that anthropology "must become as fully as possible a possession of the people of the world" (Hymes 1969, cited in Frisby, 2013), the relational model of anthropology ${ }^{2}$ that underpins Western's work and that I advocate below requires not only sharing research findings with the subjects, but ensuring that these findings are examined and assessed by the subjects themselves.

This is particularly important since anthropology has mostly been what I would describe as "non-fair trade"-insofar as it has generated more benefits (material and intellectual) for the outsider "researcher" than the insider researched. Against this backdrop, there has to be a better scale to weigh the value of shared life experiences. The value of "being represented" on a 
few platforms (i.e., academic, media, and/or political platforms) is insufficient and inadequate, especially since-for many reasons-those platforms tend to be detached from the subjects' actual living conditions and are frequently in countries whose politics are at odds with these very subjects' welfare.

\section{Listening through and beyond the Academic Platform}

"Listening with Displacement" advocates in a particular humanitarian direction that argues for the need to disrupt not only academic but also social and political discourses in perceiving, referring to, and representing displacement. This makes me wonder how effective the academic platform is for it. After all, the very nature of being an academic or a reader of academic materials suggests that one has a degree of receptiveness and critical thinking that arguably gives some ground to empathetic understandings of migration. In effect, in academia as well as in concert halls and themed festivals such as the above-mentioned Beyond Borders Scotland, we are effectively talking to people who have already "listened" or at least "made the choice to listen." But what about the others? How do we engage them?

While I agree with Western that decolonization is strongly associated with "listening" (as in: engagement), sound and history do not necessarily challenge long-established colonialist views. Since "anthropological representations are not neutral, but embedded in power relations" between the powerful and those who have less power (Santos uses the terms North and South; Santos 2015), the decolonization of anthropology must start necessarily from dismantling and challenging colonialist vocabularies, ${ }^{3}$ and ways of thinking and doing. The decolonization of anthropology does not, therefore, primarily happen through studying, representing, and/or documenting people's experiences differently, but rather (and to begin with) through re-examining the notion of anthropology itself, its motives, agents, dynamics, and outcomes (Carrier 2012). ${ }^{4}$

If "listening" within and through the academic platform is limited in the ways outlined above, what of "listening" outside academia? It is by now clear how dogmatism, polarization, sowing and growing sentiments of entitlement, lying, and promises of prosperity by eliminating the "others" (among several other tools) have been classic political tools. Furthermore, these tools almost always seem to increase, first and foremost, the wealth of the few and the fewer.

Even when politicians' lies are exposed, that does not guarantee that their supporters will engage in critical thinking, let alone modify their views (Hodson 2013). The crisis we face is thus that of a model of being that is compartmentalized, reactive yet detached, shortsighted (and short-tempered), with a sense of entitlement, and driven by ideology. Therefore, my hopes do not lie in getting information across by any preferable method. People are flooded daily with both random and systematically manipulated information in different formats and have developed the ability to select, ignore, and detach themselves from any piece that challenges them. Instead, what is needed is the much-needed facilitation of positive encounters and redefining the understanding of integration as an effort that both the local and the incomer have to make, not through information, but through contact and meaningful encounters; if such encounters do not yet exist, they must be created "in order to live with dignity": "What we all have in common is that we all have to fight against many obstacles in order to live with dignity-that is to say, to live well. There are many obstacles, but they all have a family resemblance ... [The obstacles] all have something in common: to wit, the infinite accumulation of unequal differences on the unjust behalf of very few" ( Santos 2015: 294). Which returns us to the question: what role can listening play in overcoming these obstacles to "live well"? 


\section{Listening With "Each Other"? Mindfulness, Empathy, and Transformative Interactions}

As noted above, I see the potential of "Listening with Displacement" not mainly as an anthropological model but rather as a relational social practice, as a method for a two-way integration. We find examples of that in the interactions that were generated by the sound quests Western and his collaborators embarked on. ${ }^{5}$

Through listening with each other, both the "local" and the "incomer" can explore, share, and exchange their perceptions, knowledge, and impressions of the place (in this method, through sound). However, this requires what I consider to be the increasingly necessary global need for a mindful being, of "being fully aware of the gross and/or ultimate properties of phenomena at the moment they enter into the attentional sphere" (Shonin et al. 2015: vii).

As much as I believe that a sound sample and a still image in a featured "event" have the potential to facilitate some understanding and empathy, ${ }^{6}$ I still wonder whether this would change the reaction or perception of the listener when they encounter a similar event in their own life. The space left for imagination might make people imagine "faces" they can empathize with (or be angry at), and yet this does not necessarily mean that they will behave, think, or feel the same way in an actual encounter. Instead, I would propose the potential for both individual and collective mindfulness to facilitate such a process, where collective mindfulness is conceptualized as "a combination of ongoing scrutiny of existing expectations, continuous refinement and differentiation of expectations based on newer experiences, willingness and capability to invent new expectations that make sense of unprecedented events, a more nuanced appreciation of context and ways to deal with it, and identification of new dimensions of context that improve foresight and current functioning" (Butler and Gray 2006: 216). Changing the format or the amount of information disseminated to people may not lead to change, and yet through investing in mindfulness - which, as Patrick Comstock (2015) argues, has the potential to enhance the democratic ethos - it may be possible to dismantle the hateful ideologies that envelop and limit the thoughts and compassion of many people.

Mindfulness may be embodied and enacted in diverse ways, including through a form of listening that parallels what Amy Paulson (2015, It's Time to Shift the Paradigm section, para. 3) refers to as a model of mindful philanthropy, a model "that is rooted in presence, mutuality, and collaboration. One that remembers that all the great movements for social change start at the grassroots level. And, one that values authentic connection-which starts from a process of profound self-examination-of noticing what's going on inside us and how that informs what goes on around us." This mutuality and relationality, which is what Western argues for in "Listening with Displacement," should not solely describe a mode of data collection but should also be the responsibility we take upon ourselves when studying troubled contexts in particular, where "documenting" and "reporting" transcends into "activism." While this activism may be considered to be controversial by some scholars, the position and role of the "intellectual activist" - which is how Santos identifies himself (2015: 317) — suggests "a possible way of living the impossibility of communicating the unsayable in a productive way, thereby creating new possibilities" (ibid.: 318).

With mindfulness, compassion, and belief in justice and equity, we all have the potential to listen, live, and respond as engaged anthropologists and activists. We just need to fight for our right and responsibility to engage with ourselves and each other through the perspective of a compassionate inquirer (Bishop 2017). In my view, this perspective extends the humanitarian potential of "rehumbling" ethnography (Western, this volume) beyond the zone of not knowing and into the zone of social engagement and collective activism. 
RIHAB AZAR is a Syrian oud player and primary school music teacher. Recognized by Arts Council England as "a musician of exceptional promise" in 2016, Rihab received a Chevening scholarship (2015) through which she received an MA in music education at IOE, UCL, and is a graduate of the Conservatoire of Damascus (2014).

\section{NOTES}

1. See www.sdaid.org.

2. The term "relational anthropology" is tied to the work of Desmond (2014), who argues that ethnography needs to move from substantialism toward relationalism. I believe this is exactly what Western argues in "Listening with Displacement."

3. In this article I have intentionally avoided using words like West, East, hosts, refugees, borders, as it has been my intention to move away from terms that I perceive as colonialist, nationalist, nonfluid, non-nuanced, generalizing, and/or reductive.

4. The notion of "studying up" and to research the "powerful" discussed by Nader (1972) seems like a step in the right direction, although I would call it studying "inward." I agree with Okely and Callaway (1992: 228) that this does not mean that "anthropology should be about the anthropologist's self: rather, it must be informed by it."

5. One example is the story of Part III of the project (see Western, this volume).

6. I do not intend to point to "helpful" empathy only. Hammond and Kim (2014) point out how empathy can be both helpful and harmful.

\section{REFERENCES}

Bishop, Elizabeth. 2017. "Finding Joy In Service: Exploring Compassionate Curiosity with Dr. Gabor Maté.” SWHELPER, 10 February. https://www.socialworkhelper.com/2017/02/10/finding-joyservice-exploring-compassionate-curiosity-dr-gabor-mate.

Butler, Brian S., and Peter H. Gray. 2006. "Reliability, Mindfulness, and Information Systems." MIS Quarterly 30 (2): 211-224. https://doi.org/10.2307/25148728.

Carrier, James G. 2012. “Anthropology after the Crisis.” Focaal 64: 115-128. https://doi.org/10.3167/ fcl.2012.640110.

Comstock, Patrick. 2015. “The Politics of Mindfulness: A Response to 'Mindfulness, Democracy, Education." Democracy and Education 23 (2). https://democracyeducationjournal.org/home/vol23/iss2/8.

Frisby, Kelly. (2013). Decolonizing Anthropology. POLITICAL ANTHROPOLOGY. https://politicalan thro.wordpress.com/decolonizing-anthropology/

Desmond, Matthew. 2014. "Relational Ethnography." Theory and Society 43 (5): 547-579.

Gardner, Katy, and David Lewis. 2015. Anthropology and Development: Challenges for the Twenty-First Century. London: Kindle.

Hammond, Meghan Marie, and Sue J. Kim. 2014. Rethinking Empathy through Literature. London: Routledge.

Hodson, Gordon. 2013. “Facts? No Thanks, I’ve Got Ideology.” Psychology Today blog, 17 October. https://www.psychologytoday.com/us/blog/without-prejudice/201310/facts-no-thanks-i-vegot-ideology.

Morris, Christian. 2018. “Nigel Osborne Interview." Composition:Today, 30 January. http://www.com positiontoday.com/interviews/nigel_osborne.asp.

Nader, Laura. 1972. “Up the Anthropologist: Perspectives Gained From Studying Up." https://eric.ed .gov/?id=ED065375.

Okely, Judith, and Helen Callaway. 1992. Anthropology and Autobiography. London: Routledge. 
Paulson, Amy. 2015. "Why We Need More Mindfulness in Philanthropy." Thousand Currents, 27 September. https://thousandcurrents.org/why-we-need-more-mindfulness-in-philanthropy.

Santos, Boaventura de Sousa. 2015. Epistemologies of the South: Justice Against Epistemicide. London: Routledge. Kindle.

Shonin, Edo, William Van Gordon, and Nirbhay N. Singh. 2015. Buddhist Foundations of Mindfulness. Cham: Springer. 